\section{Direct Colony Sequencing of Plasmid DNA by Dye Terminator Methods}

\section{BioTechniques 29:442-444 (September 2000)}

Direct colony sequencing of plasmid DNA is a powerful technique. Radioactive or fluorescent dye primer methods are the reported direct colony sequencing methods $(2-4,6)$. Recently, dye terminator sequencing chemistry (7) has been improved by the introduction of a modified enzyme, AmpliTaq ${ }^{\circledR}$ DNA polymerase FS (8), as well as a new d-Rhodamine and BigDye ${ }^{\mathrm{TM}}$ terminator (PE Biosystems, Foster City, CA, USA) (5) that enhances sensitivity while reducing the background. The direct colony sequencing strategy is pre- sented here and suggests that it is possible to use a BigDye terminator as well as dye primer sequencing.

Plasmid pBluescript ${ }^{\circledR} \mathrm{KS}+$ (Stratagene, La Jolla, CA, USA) was transformed to DH5 $\alpha$-competent cells using the method of Hanahan (1). The appropriate volume of transformed competent cells was transferred to an LB agar plate containing $100 \mu \mathrm{g} / \mathrm{mL}$ ampicillin and incubated overnight at $37^{\circ} \mathrm{C}$.

A single bacterial colony with a diameter of 2-2.5 mm was picked up and then suspended in a reagent mixture containing $6 \mu \mathrm{L}$ BigDye Terminator Ready reaction mixture (PE Biosystems); $2 \mu \mathrm{L}$ (3.2 pmol) - 20 M13 primer and $7 \mu \mathrm{L}$ double-distilled water. The reactions were carried out in a model 480 DNA thermal cycler (PE Biosystems) at $94^{\circ} \mathrm{C}$ for $3 \mathrm{~min}$ and then for $25-40$ cycles of $96^{\circ} \mathrm{C}$ for $30 \mathrm{~s} ; 50^{\circ} \mathrm{C}$ for $15 \mathrm{~s}$;
Table 1. Results from Colony Sequencing Using Different Cycle Numbers

\begin{tabular}{|ccc|}
\hline $\begin{array}{c}\text { Sample } \\
\text { No. }\end{array}$ & $\begin{array}{c}\text { Cycle } \\
\text { No. }\end{array}$ & $\begin{array}{c}\text { Reading } \\
\text { Length }\end{array}$ \\
\hline 1 & 25 & 580 \\
2 & 25 & 400 \\
3 & 35 & 440 \\
4 & 35 & 700 \\
5 & 40 & 520 \\
6 & 40 & 390 \\
\hline
\end{tabular}

and $60^{\circ} \mathrm{C}$ for $2 \mathrm{~min}$. Each Sephadex ${ }^{\circledR}$ G50 spin column (Amersham Pharmacia Biotech, Piscataway, NJ, USA) loaded with the reaction product was microcentrifuged at $730 \times g$ for 2 min to

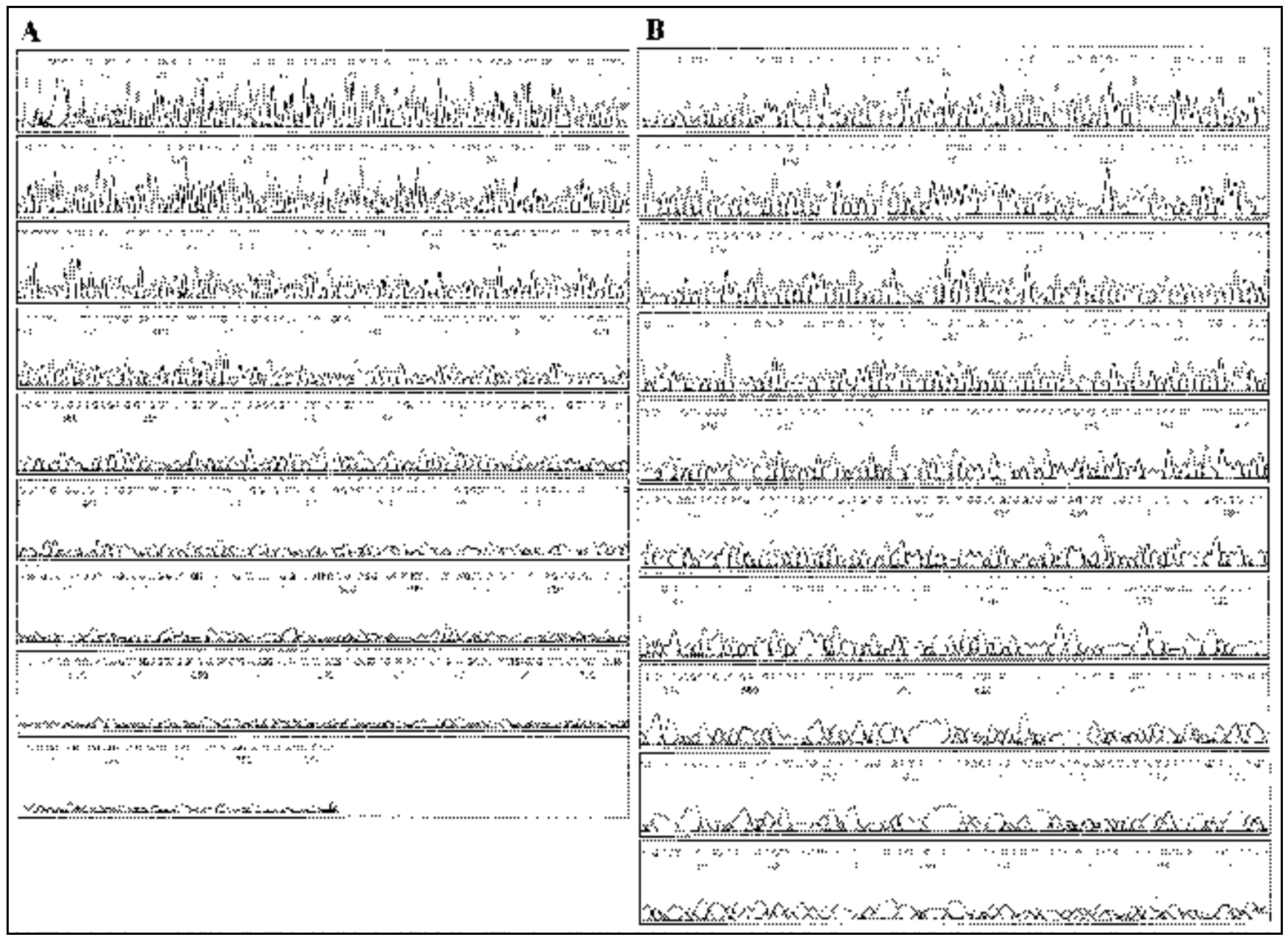

Figure 1. An electropherogram of sequencing using the BigDye terminator. (A) pBluescript transformed into DH5 $\alpha$ (Sample 4). (B) pBluescript prepared by the alkaline lysis method. 
remove the unincorporated dye-labeled terminators. Each sample was then isolated by ethanol/sodium acetate precipitation and suspended in $20 \mu \mathrm{L}$ template suppression reagent and subjected to the ABI PRISM ${ }^{\mathrm{TM}} 310$ genetic analyzer (PE Biosystems).

A colony of similar size was suspended in PBS, diluted and $10^{-5}$ amounts of the solution were transferred to an LB agar plate containing $100 \mu \mathrm{g} / \mathrm{mL}$ ampicillin. It was incubated overnight at $37^{\circ} \mathrm{C}$ to count the number of cells per colony.

To characterize the inserts of several isolated cDNA clones, I developed a one-step dye terminator sequencing protocol for the plasmid from bacterial colonies that omit any DNA preparation. I found that single-colony sequencing with the BigDye terminator kit yielded about 500 bases of sequence information (Table 1, Figure 1). Increasing the number of cycles to $40 \mathrm{did}$ not improve the signal strength. About $5.6 \times 10^{7}$ cells were included in a colony that was similar in size to the colony used for sequencing.

The results indicate that the direct colony sequencing, without additional preparation, has an almost similar quality, length and sequencing as that using a plasmid DNA prepared by the smallscale alkaline lysis method (Figure 1). This is because pBluescript is a highcopy-number plasmid. Similar experiments using a pBR322 derivative yielded no sequence (data not shown). pBluescript is a vector that contains the bacteriophage M13 origin of DNA replication, inserted in opposite orientations into a vector derived from a pUC plasmid. Replication of plasmid DNA is carried out by subsets of enzymes used to duplicate the bacterial chromosome. However, different plasmids use different subsets and replicate to different extents in their hosts. A pUC plasmid reaches copy numbers as high as 500 700/cell, and pBR322 and its derivatives are maintained at the minimal level of 15-20 plasmid molecules/host-cell chromosome (9). Therefore, $5.6 \times 10^{7}$ DH5 $\alpha$ cells may contain an estimated $5.6 \mathrm{pmol}$ (5 ng) of plasmid pBluescript $\mathrm{KS}+$. The quantity is similar to the one Kilger et al. used for sequencing by incorporating $\left[\alpha^{-33} \mathrm{P}\right] \mathrm{dATP}$ or fluorescently labeled primers (3). Similarly, the plasmid pBluescript and other primers (KS, M13Reverse) yielded results equivalent to the quality and length of the sequences (data not shown). The conclusion is that dye terminator sequencing using the BigDye terminator is as helpful as dye primers for direct colony sequencing, and pUC and its derivatives would be best used for this approach.

\section{REFERENCES}

1.Hanahan, D. 1983. Studies on transformation of Escherichia coli with plasmids. J. Mol. Biol. 166:557-580.

2.Hofmann, M.A. and D.A. Brian. 1991. Sequencing PCR DNA amplified directly from a bacterial colony. BioTechniques 11:30-31.

3.Kilger, C., M. Kring, H. Poinar and S. Pääbo. 1997. "Colony sequencing": direct sequencing of plasmid DNA from bacterial colonies. BioTechniques 22:412-416.

4.Krishnan, B.R., R.W. Blakesley and D.E. Berg. 1991. Linear amplification DNA sequencing directly from single phage plaques and bacterial colonies. Nucleic Acids Res. 19:1153.

5.Lee, L.G., S.L. Spurgeon, C.R. Heiner, S.C. Benson, B.B. Rosenblum, S.M. Menchen, R.J. Graham, A. Constantinescu et al. 1997. New energy transfer dyes for DNA sequencing. Nucleic Acids Res. 25:2816-2822.

6.Murray, V. 1989. Improved double-stranded DNA sequencing using the linear polymerase chain reaction. Nucleic Acids Res. 17:8889.

7.Prober, J.M., G.L. Trainor, R.J. Dam, F.W. Hobbs, C.W. Robertson, R.J. Zagursky, A.J. Cocuzza, M.A. Jensen and K. Baumeister. 1987. A system for rapid DNA sequencing with fluorescent chain-terminating dideoxynucleotides. Science 238:336-341.

8.Reeve, M.A. and C.W. Fuller. 1995. A novel thermostable polymerase for DNA sequencing. Nature 376:796-797.

9.Sambrook, J., E.F. Fritsch and T. Maniatis. 1989. Molecular Cloning: A Laboratory Manual, 2nd ed. CSH Laboratory Press, Cold Spring Harbor, NY.

I thank Takeshi Endo and Tsuneko Fujii for excellent technical support and expert computer maintenance. Address correspondence to Ms. Chikako Sasho, Center for Research and Education, Room C10, Osaka University Medical School, 2-2 Yamadaoka, Suita, Osaka 565-0871, Japan. email:yyama@biochem.med.osaka-u.ac.jp

Received 24 January 2000; accepted 12 April 2000.

Chikako Sasho

Osaka University

Medical School

Osaka, Japan

\section{Isolation of Full-Length cDNA Clones Using SMART ${ }^{\mathrm{TM}}$ cDNA and a Biotin-Streptavidin Bead System}

BioTechniques 29:444-450 (September 2000)

The use of streptavidin-coated beads with biotinylated DNA fragments to enrich for nucleic acids such as microsatellite-containing regions of genomic DNA (5) and cDNAs $(3,7,9)$ is well documented. Expanding on this use of biotinylated DNA fragments as capture probes, we have developed a simple method for rapidly selecting full-length cDNAs from amplifiable cDNA. The method presented is an iterative process that progressively enriches for cDNAs of interest with each iteration by hybridizing SMART ${ }^{\mathrm{TM}}$ cDNA (Clontech Laboratories, Palo Alto, CA, USA) to a biotinylated probe and capturing hybrids via streptavidincoated beads.

Our method has several advantages. Traditional methods of recovering fulllength cDNAs by synthesizing cDNA, cloning into appropriate vectors, transforming or transfecting bacteria and screening the resultant library with radioactive probes generally require two to three weeks and are rather material and labor intensive. In contrast, using the method described here, full-length cDNAs from abundant messages may be captured through a single round of enrichment in three days. Clones of less-abundant messages take about one week. By using more than one probe per hybridization, enrichment for several cDNAs can be performed in the same hybridization. Unlike rapid amplification of cDNA ends (RACE) methods (6), no sequence information or oligonucleotide design is needed, and solution-hybridization is simple and presents far fewer optimization challenges than does RACE amplification. Products of the present method are contiguous cDNA molecules, which obviates the need and risk involved in subcloning to generate complete ORFs.

The method described here requires amplifiable cDNA, a PCR-generated biotinylated probe and only one ex- 